\title{
IMPLICATIONS OF REFUSAL SCHOOL ON THE PSYCHIC AND ACADEMIC FACTORS OF MADRASAH IBTIDAIYAH STUDENTS
}

\author{
Amrih Widodo', Fauzi Annur ${ }^{2}$ \\ ${ }_{1,2}$ Pascasarjana IAIN Salatiga \\ 1,2 Jalan Lkr. Sel. Salatiga No. Km. 2, Pulutan, Kecamatan Sidorejo, Jawa Tengah \\ Email: amrihwidodo35@gmail.com ${ }^{1}$, fauziannur18@gmail.com²
}

\begin{abstract}
:
This study aims to answer two crucial problems in education, especially school refusal for Madrasah Ibtidaiyah students. First, to express the students' reasons why they do school refusal. The second is to reveal the implications for the students' psychological and academic factors. In this study, the researcher used a descriptive qualitative approach to describe natural phenomena or human manipulation phenomena. The data was obtained through an interview with the seven students of Madrasah Ibtidaiyah Negeri 1 Semarang. To analyze the data, the researcher used non-statistical methods with interactive methods developed by Miles and Huberman. This research indicated that the students refuse to go to school because of physical conditions such as getting a fever or sick and psychological conditions such as not doing the homework and being bullied. The absence of the students during the learning process, especially Mathematics, affects their academic achievement.
\end{abstract}

\begin{abstract}
Abstrak:
Penelitian ini bertujuan untuk menjawab dua masalah krusial dalam dunia pendidikan, khususnya school refusal pada siswa Madrasah Ibtidaiyah. Pertama, untuk mengungkapkan alasan siswa melakukan penolakan sekolah. Kedua, untuk mengungkap implikasi faktor psikologis dan akademis siswa. Dalam penelitian ini peneliti menggunakan pendekatan kualitatif deskriptif untuk mendeskripsikan fenomena yang ada, baik fenomena alam maupun manipulasi manusia. Data diperoleh melalui wawancara kepada tujuh siswa Madrasah Ibtidaiyah Negeri 1 Semarang. Untuk menganalisis data, peneliti menggunakan metode non statistic dengan metode interaktif yang dikembangkan oleh Miles dan Huberman. Hasil penelitian menunjukkan bahwa siswa menolak bersekolah karena kondisi fisik seperti demam atau sakit dan kondisi psikologis seperti tidak mengerjakan PR dan di-bully. Ketidakhadiran siswa selama proses pembelajaran khususnya pelajaran Matematika mempengaruhi prestasi akademiknya.
\end{abstract}

Keywords:

School Refusal, Psychic, Academic

How to Cite: Widodo, A. \& Annur, F. (2021). Implication of Refusal School on the Psychic and Academic Factors of Madrasah Ibtidaiyah Students. Lentera Pendidikan : Jurnal Ilmu Tarbiyah dan Keguruan, 24(1), 12-24. https://doi.org/10.24252/lp.2021v24n1i2.

\section{INTRODUCTION}

The mandate of the constitution emphasizes that all citizens must complete school for up to 9 years. There is no activity outside during school hours other than learning at an 
educational institution for Kindergarten to Junior High School. It assures everyone that educational institutions as stakeholders must ensure their students participate in a series of lessons.

A school is a strategic place for the growth and development of students. All school components are presented to make all parties feel lucky and satisfied with this. If only one component is experiencing problems, it will certainly hinder students' growth and development in the school environment. Therefore, various components must be fulfilled optimally, such as curricula, creative-innovative learning designs, and a learning model that leads to intellectual intelligence and attention to students' mental formation and attitudes.

As one psychologist, Daniel Goleman said, Intelligence Quotient (IQ) or intellectual intelligence only contributes $20 \%$ of a person's success, while $80 \%$ is other factors such as emotional intelligence. Meanwhile, existing research proves that emotional intelligence directly influences students' academic achievement (Andiri, Jajat \& Sulthoni, 2017). In response to this challenge, China has reformed its educational system since 1985, emphasizing the importance of character education and the importance of one's mental and attitude (Muslich, 2015: 40).

The presence of character education has made the learning model completely changed from previously only the range of daily test scores, midterm exams, final semester exams towards attitude formation, training responsibilities, learning with teams, modeling, etc. At the same time, students will be more relaxed in living their learning life at school. As with fun learning, there is a relaxed, pressure-free, attractive atmosphere, awakening interest in learning, full involvement, feelings of joy, and high concentration (Mintasih, 2016).

Following existing data, in 2017/2018, children who dropped out of school at the public and private primary school levels were reviewed from some of the largest provinces in Indonesia, amounting to 3,596 students for West Java, 2,238 students for Central Java, and 1,980 students for East Java. This amount is not small, but it is quite concerning. Dropping out of school means that several problems are not immediately resolved in the educational institution's learning process.

Madrasah Ibtidaiyah Negeri 1 Semarang is an educational institution with many students, amount of 631 students. In addition to having a good institution, the problem that often arises is student absence, which is about 30 students who do not attend school regularly. Researchers have tried to open documents available at school and asked some of the teachers around them. Several students were absent without information. Thus, that information attracted attention to research the importance of a school refusal study in terms of students' psychological and academic factor analysis. This study was interesting because it tried to explore problems regarding the school refusal process, deepened what happened, and analyzed its relationship in terms of student psychology and academics. 


\section{RESEARCH METHOD}

This study used a descriptive qualitative approach, in which the research aimed to describe existing phenomena, both natural phenomena or human engineering (Sukmadinata, 2012: 72). Everything related to the school refusal process and the various reasons and conditions recorded and described in this study. The data was obtained through an interview with the seven students of Madrasah Ibtidaiyah Negeri 1 Semarang. The research's data analysis used non-statistical methods using interactive methods developed by Miles and Huberman as quoted and developed by Sugiyono (2005: 92-95). The analysis steps in this interactive model could be explained as follows: (a) Data collection. The data obtained in the field are recorded in descriptive narrative form, namely descriptions of data obtained from interviews, observations, and documents related to school refusal, including students' psychological and academic conditions (mental disorders). (b) Data Reduction. Data reduction involves selecting, concentrating attention, simplifying, abstracting, and transforming raw data that emerge from field notes. (c) Data Presentation (data display). At this stage, data on field findings are presented in the form of narrative text, namely a written description of the process and the reasons in detail for refusal to attend school and a complete framework of its relationship with the psychological and academic conditions of students. (d) Conclusion and verification. Drawing conclusions and verification is an effort to find the meaning of the data components presented by looking at regularity patterns, clarity, configuration, and causal relationships.

\section{RESULTS AND DISCUSSION}

Schools are, for most students, a great place to learn and play. Interesting and fun learning, creative, caring, and friendly teachers, fun learning friends certainly make students feel at home studying at school or madrasah and willing to attend school every day. However, for some students, school is a boring and even scary place.

In several meetings and observations, researchers found many findings related to students' perceptions at Madrasah Ibtidaiyyah Negeri 1 Semarang on the phenomenon of school refusal or rejecting school. Below is a table regarding the process of school refusal or rejecting the school for related students.

Table 1. The Reasons for School Refusal

\begin{tabular}{cllll}
\hline Name & \multicolumn{1}{c}{$\begin{array}{c}\text { The Reason for } \\
\text { Absence }\end{array}$} & \multicolumn{1}{c}{ Information of School Refusal } & \\
\hline Irsyad & Diarrhea and Dizziness & $\begin{array}{l}\text { When Mathematics schedule, he felt } \\
\text { dizziness and diarrhea }\end{array}$ \\
\hline Pramudya & $\begin{array}{l}\text { Diarrhea, dizziness, } \\
\text { cough, and flu }\end{array}$ & $\begin{array}{l}\text { Lazy to go to school because they were } \\
\text { embarrassed to get bad grades }\end{array}$ \\
\hline Keyla & $\begin{array}{l}\text { Stomachache, } \\
\text { dizziness, cough, and } \\
\text { flu }\end{array}$ & $\begin{array}{l}\text { When Mathematics schedule, she felt } \\
\text { dizziness and diarrhea }\end{array}$ & & \\
\hline
\end{tabular}




\begin{tabular}{|c|c|c|}
\hline Adli & Fever and nosebleeds & $\begin{array}{l}\text { When Mathematics schedule, he felt } \\
\text { dizziness and diarrhea }\end{array}$ \\
\hline Nazifa & Stomachache & $\begin{array}{l}\text { She did not want to go to school when she } \\
\text { knew that she could not go home early } \\
\text { because her parents cannot pick her up, so } \\
\text { she has to wait at madrasah until noon or } \\
\text { even in the afternoon. }\end{array}$ \\
\hline Arum & Fever & $\begin{array}{l}\text { Initially, she often complained that he was } \\
\text { sick and did not want to go to school, even if } \\
\text { she asked to change schools. After being } \\
\text { asked by her aunt, she finally honestly that } \\
\text { she did not want to go to school because she } \\
\text { was afraid of one of her friends. After all, she } \\
\text { was often bullied. }\end{array}$ \\
\hline Adnan & Fever & $\begin{array}{l}\text { When sick or when he had not done his } \\
\text { homework. }\end{array}$ \\
\hline
\end{tabular}

The table above provides a good overview for the researcher to fully illustrate the students' views on the school refusal process. In general, students do not attend school due to illness. It shows the various diseases experienced by the students. Meanwhile, school refusal generally occurs on the grounds of feeling overwhelmed by certain subjects.

Some of the conditions behind school absenteeism are abdominal pain or diarrhea in almost all absent students. Some of the others are headache, fever, and cough. Meanwhile, headache conditions rank second after stomach pain. In contrast, the lowest order is dengue fever. It only happened in one case experienced by students.

The third column illustrates the school refusal reasons, which were officially conveyed by students directly through small talk. The most rejection made by students was feeling burdened by Mathematics. They said that when there was a Mathematics schedule, then they complained of dizziness and pain. Meanwhile, the following reason was feeling embarrassed if he/she got a bad score. It opens up opportunities, whether there is value reinforcement among students.

The next reason of less interesting, which became important, was the fear of being bullied by classmates. This condition could be discovered after one of his family asked, and in a long time, he dared to answer. Another case was when the students had not done homework yet. This was also conveyed after previously affirming that a student always went to school, except when he/she was sick, then he/she did not want to go to school when the homework had not finished yet. The last reason was a student's concern that she could not be at home early because her parents could not pick her up after school. From those cases, students refused to go to school.

\section{Psychical and Academical Conditions}

These two conditions are very important to note, considering that psychological conditions are a vital foundation for the survival of a person's life. Meanwhile, academic points are tools for taking and outputting the continuity of a person's life. The following 
table explains the psychological and academic conditions of students who refuse to go to school at Madrasah Ibtidaiyyah Negeri 1 Semarang:

Table 2. The Psychological Conditions

\begin{tabular}{|c|c|c|c|c|}
\hline Name & $\begin{array}{c}\text { Dominant } \\
\text { Activities at } \\
\text { Home }\end{array}$ & $\begin{array}{l}\text { Character and } \\
\text { Interaction } \\
\text { with friend }\end{array}$ & $\begin{array}{c}\text { Physical } \\
\text { Condition } \\
\text { during the } \\
\text { Interview }\end{array}$ & $\begin{array}{l}\text { Always Complained } \\
\text { about }\end{array}$ \\
\hline Irsyad & $\begin{array}{l}\text { Playing } \\
\text { PlayStation } \\
\text { and Youtube }\end{array}$ & $\begin{array}{l}\text { Extroverted, } \\
\text { more friendly, } \\
\text { and has lots of } \\
\text { friends. }\end{array}$ & $\begin{array}{l}\text { Healthy, clean, } \\
\text { and has no } \\
\text { symptoms of } \\
\text { illness. }\end{array}$ & $\begin{array}{l}\text { Limp, lethargic, } \\
\text { nauseous. Besides } \\
\text { that, when there is } \\
\text { Mathematics, he } \\
\text { felt dizziness and } \\
\text { diarrhea. }\end{array}$ \\
\hline Pramudya & $\begin{array}{l}\text { Playing } \\
\text { PlayStation } \\
\text { and Youtube }\end{array}$ & $\begin{array}{l}\text { Extroverted, } \\
\text { more friendly, } \\
\text { and has lots of } \\
\text { friends. }\end{array}$ & $\begin{array}{l}\text { Healthy, clean, } \\
\text { and has no } \\
\text { symptoms of } \\
\text { illness. }\end{array}$ & $\begin{array}{l}\text { He felt dizziness, } \\
\text { weak, and laziness in } \\
\text { going to school. Also, } \\
\text { he was embarrassed } \\
\text { about getting low } \\
\text { grades. }\end{array}$ \\
\hline Keyla & $\begin{array}{l}\text { Playing } \\
\text { (general) }\end{array}$ & $\begin{array}{l}\text { Introverted and } \\
\text { has no friend } \\
\text { (few friends). }\end{array}$ & $\begin{array}{l}\text { Healthy, clean, } \\
\text { and has no } \\
\text { symptoms of } \\
\text { illness. }\end{array}$ & $\begin{array}{l}\text { When there is a Math } \\
\text { lesson schedule, she } \\
\text { often complained of } \\
\text { dizziness, weakness, } \\
\text { lethargy, and } \\
\text { diarrhea. }\end{array}$ \\
\hline Adli & $\begin{array}{l}\text { Playing } \\
\text { PlayStation } \\
\text { and Youtube }\end{array}$ & $\begin{array}{l}\text { Extroverted, } \\
\text { more friendly, } \\
\text { and has lots of } \\
\text { friends. }\end{array}$ & $\begin{array}{l}\text { Healthy, clean, } \\
\text { and has no } \\
\text { symptoms of } \\
\text { illness. }\end{array}$ & $\begin{array}{l}\text { When there is a math } \\
\text { lesson schedule, he } \\
\text { often complained of } \\
\text { dizziness, fever, and } \\
\text { diarrhea. }\end{array}$ \\
\hline Nazifa & $\begin{array}{l}\text { Playing } \\
\text { cellphones } \\
\text { and Martial } \\
\text { Arts }\end{array}$ & $\begin{array}{l}\text { Extroverted, } \\
\text { more friendly, } \\
\text { and has lots of } \\
\text { friends. }\end{array}$ & $\begin{array}{l}\text { Healthy, clean, } \\
\text { and has no } \\
\text { symptoms of } \\
\text { illness. }\end{array}$ & $\begin{array}{l}\text { Feeling tired, } \\
\text { dizziness and lazy to } \\
\text { go to school when } \\
\text { she knew she would } \\
\text { not be going home } \\
\text { early because her } \\
\text { parents could not } \\
\text { pick her up. She had } \\
\text { to wait at the } \\
\text { madrasah until noon } \\
\text { or even in the } \\
\text { evening. }\end{array}$ \\
\hline Arum & $\begin{array}{l}\text { Playing } \\
\text { cooking }\end{array}$ & $\begin{array}{l}\text { Introverted, } \\
\text { she seems to } \\
\text { harbour } \\
\text { something from }\end{array}$ & $\begin{array}{l}\text { Healthy, clean, } \\
\text { and has no } \\
\text { symptoms of } \\
\text { illness. }\end{array}$ & $\begin{array}{l}\text { Dizziness and } \\
\text { initially often } \\
\text { complained of being } \\
\text { sick of not wanting to } \\
\text { go to school, even }\end{array}$ \\
\hline
\end{tabular}


her face and has

few friends.

asking to change

schools. After being asked by her aunt, she finally said that she did not want to go to school because she was afraid of her friends. After all, she was often bullied.

$\begin{array}{llll}\text { Adnan } & \text { Playing } & \text { Extroverted } & \text { Healthy, clean, Fever and dizziness } \\ & \text { Football } & \text { and more and has no when he had not } \\ & \text { sociable, has symptoms of done his homework. } \\ & \text { lots of friends. } & \text { illness. }\end{array}$

From the description of table 2, the first point, in general, shows that playing cellphones, PlayStations, and youtube are students' main habits when staying at home. However, some of them liked to spend their time at home playing football, cooking, and the rest playing Pancak Silat (martial art). Meanwhile, on the second point, almost all of them were extroverted and had many friends. The rest have the opposite character, namely introverts who have one or two friends at home and school. The next point, the physical condition was visible. Everyone was healthy, clean, and there were no visible symptoms of illness. Furthermore, the last one was a condition that there were students who were always complaining. In general, they always complained of dizziness, fever, and diarrhea.

Table 3. Academical Conditions

\begin{tabular}{|c|c|c|c|c|}
\hline Name & $\begin{array}{l}\text { Preferred } \\
\text { Subjects }\end{array}$ & $\begin{array}{c}\text { Preferred } \\
\text { Extracurricular } \\
\text { Activities }\end{array}$ & Preferred Teacher & Student Score \\
\hline Irsyad & $\begin{array}{l}\text { English } \\
\text { Language }\end{array}$ & $\begin{array}{l}\text { Football and } \\
\text { Swimming }\end{array}$ & $\begin{array}{l}\text { Mr. Amrih, Ngatirin, } \\
\text { and Aryo }\end{array}$ & Medium \\
\hline Pramudya & $\begin{array}{l}\text { English } \\
\text { Language }\end{array}$ & Football & $\begin{array}{l}\text { Mr. Amrih, Ngatirin, } \\
\text { and Ajik }\end{array}$ & Lowest \\
\hline Keyla & Colouring & Playing & Mrs. Juliah & Medium \\
\hline Adli & Sport & $\begin{array}{l}\text { Football and } \\
\text { Swimming }\end{array}$ & $\begin{array}{l}\text { Mr. Amrih, Ajik, and } \\
\text { Bowo }\end{array}$ & Low \\
\hline Nazifa & Thematic & Swimming & $\begin{array}{l}\text { Mr. Amrih, Mrs. Lely, } \\
\text { Hanik, and Santi }\end{array}$ & Medium \\
\hline Arum & $\begin{array}{l}\text { Natural } \\
\text { Sciences }\end{array}$ & $\begin{array}{l}\text { Reading books } \\
\text { and swimming }\end{array}$ & Mrs. Santi & Highest \\
\hline Adnan & Sport & Football & $\begin{array}{l}\text { Mrs. Hanik and Mr. } \\
\text { Isnaeni }\end{array}$ & Low \\
\hline
\end{tabular}

Table 3 shows the academic conditions of students who refuse to go to school. The academic conditions appear to be average, which means that they range from the lowest to the highest. The lessons they like are varied, starting with English, thematic, colouring, sport, and natural sciences. Meanwhile, all students like extracurricular school activities, including football and swimming. There are also interested in going to the library to read 
books. The next point, all students mentioned the teachers they liked. Only one student mentions one teacher, while the others mention at least two and more. The last point is that the students have a complete score, starting from the lowest, low, medium, and highest.

In general, a Mathematics teacher, confirmed some of the students' views based on their physical and mental reaction activities. For example, Irsyad did not leave when there was a math lesson. It happened because the student concerned had difficulty working on math problems. After several times, the personal approach finally had a positive impact and slightly reduced her fear of math.

\section{Fun Learning Model at Madrasah Ibtidaiyyah}

The term learning is essential for everyone to know, especially for a teacher. This term is a development of the term teaching and learning process, or what we are more familiar with (teaching and learning process). This term emphasizes meaning in the practice of teaching and learning activities in schools, which is aimed at "processes" or things that are done by teachers and students in the teaching and learning process (Kesuma, 2013: 108).

Quality learning has several indicators: challenging, fun, encouraging exploration, encouraging successful experiences, and developing thinking skills. These five indicators must be used as guidance for schools and teachers, especially to create something challenging, especially for students' needs in the future (Hidayatullah, 2010: 160-167).

For students at the level of Elementary School or Madrasah Ibtidaiyyah, at least a fun indicator is a matter that is very important for the sustainability of their interest in learning. Therefore, the teacher, in this case, must make every effort to bring fun learning. The study results indicate that SGs (Serious Games), a digital game in the modern era, were tested in learning. The results were positive that they could increase their motivation, including their independence (Papanastasiou, Drigas, \& Skianis, 2017).

The pleasant conditions in the school environment and especially in the classroom are desirable for every student. The data above also clarifies that students at the elementary school level need pleasant conditions and atmosphere in every classroom lesson. In turn, these things make the students' motivation increase and create a strong interest in learning.

\section{Relationship between School Refusal and the students' Psychic and Academic Conditions of SD/MI (elementary school)}

School refusal occurs at all ages, including an elementary school. At this time, the child's initiative begins to develop, and he/she wants to know more about things around him. In elementary school, it is a time when students begin to recognize a new world that differs from the previous world dominant in playing. Elementary school-age is considered to be a difficult time because it is seen that children often imitate what is around them from their peers rather than their parents. 
During this period, children often do imitation, are creative, and like to play. This period is also prone to bullying, especially in the school environment, which leads to school refusals. Bullying can take physical forms such as punches, kicks, slaps, pushes, and other physical attacks. Non-physical bullying can be divided into two, namely verbal and nonverbal. Ridicule, nickname, threats, the spread of the victim's secret news, embarrassing words are considered verbal acts. Bullying is an intimidation act by a stronger party against a weaker party (Arofah, Hudaniah, \& Zulfiana, 2018). Also, bullying resulted in the students not going to school, even though it happened to the smartest student. Efforts to minimize bullying, namely: (a) pay attention to the symptoms of changes in the child, and immediately approach him, (b) be calm in acting, while convincing the child that he has received protection from future bullying behavior, (c) report to the teacher/school to immediately conducted an investigation, (d) asked the school counselor (BK teacher) to investigate what had happened, (e) asked the school to provide information about what had happened, and f) taught children how to deal with bullying (Sucipto, 2012).

In terms of students' psychosocial aspects, their development is always influenced by the social environment and achieves their personality. Based on the previous description, it can be seen that the causes of school refusal can at least be divided into two. First, it is caused from within, which is related to internal conditions, including the family environment. Second, it occurs because of interactions with the outside world, such as ridicule experiences and bullying.

The following figure explains the causes and impacts of school refusal, starting from the psychological and academic aspects and the related students' physical condition.

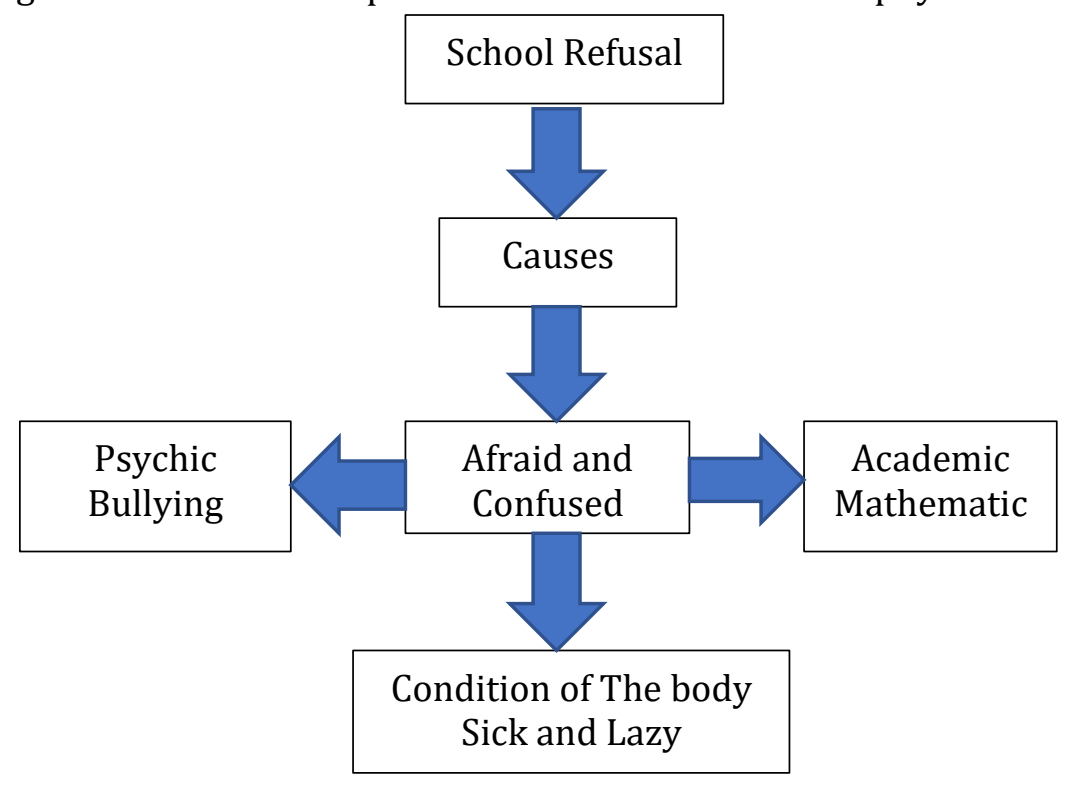

Figure 1. Causes and Impacts of School Refusal

School refusal has several causes. Among the things that stand out the most is uninterested in Mathematics. Meanwhile, the academic condition is the highest reason. The second reason is bullying. Rejection of school is very closely related to various things. It is undeniable that the fear of subjects, including mathematics is one of the causes. After 
students feel afraid of Mathematics, then in the following condition, it becomes acute fear. If there is no immediate treatment, it will make him physically sick.

Mathematics itself is one of the subjects which most disliked by school students. It is shown from the results of students' perceptions of mathematics, which is the most boring, confusing, annoying, and stressful (Intisari, 2017). Recent research results that the current Mathematics book uses a few pictures, whereas students need the figures to describe and understand. To solve this problem, the teacher must create interactive media because, through the media, some pictures and sounds can be controlled as desired. With this, the learning process will be more interesting for students (Arindiono \& Ramadhani, 2013).

If families, teachers, and school policymakers can identify the students' needs more accurately, the learning process will be more effective. Communication among parents, students, and teachers must be built based on mutual awareness and responsibility so that the students are more fulfilled and maximized from various perspectives.

Everyone has three dimensions of development, namely the physical dimension, conscience, and mind. Physical in the form within a person such as tall, short, curly hair, brown skin, etc. Conscience is a moral awareness that grows in a human being's heart and influences one's behavior. This dimension of conscience is closely related to psychological or feelings for someone.

Symptoms of school refusal that children show also include: frequency, duration, intensity, and behavior. This right is as in a case from the results of this study (Manurung, 2012). A student feels comfortable and calm when his grandmother accompanies him and waits for him to come home from school. A student once complained and asked not to go to school when his grandmother could not accompany him to school because his grandmother was sick. He experienced the third school refusal symptom described by Kearney, namely attending school but showing unexpected behavior, i.e., not to leave his grandmother. The student also experienced the first school refusal symptom, namely refusing to go to school if his grandmother did not take him to school. This condition happened once in this school year because the grandmother always accompanied him as much as possible.

A student never felt sick when he wanted to go to school. He feels fine, likes going to school, and wants to stay in school to achieve his dream of being a police officer. He did not show any physical complaints when going to school or the fourth symptom of school refusal. According to the grandmother, her grandson was so spoiled. She did not want to be separated from him. It was clear that when he first attended school, he did not want his grandmother to leave him. Until now, he went to school and came home from school always with his grandmother. Even the activities carried out at home are mostly with their grandmother.

If we look at the case above, it can be seen that the student is experiencing school refusal. In this context, the cause was due to the anxiety of being left by her grandmother. Besides, this could also happen because he was afraid of teachers who were considered 
fierce or frightening. The causes of school refusal are indeed diverse, which also impacts children's development.

Another factor that can cause school-refusal behaviour, according to Kearney \& Hugelshofer, is a lack of social support for children. The child's closest environment to influence children's development is family and school. Children still need support from their families when they go to school, but if their parents do not see the child's development, such as the mother had left for work from dawn, the father also has to work after delivering the subject. It has an impact on a child's motivation to go to school. Children have many worries about going to school, but they do not get enough support (Ballerina, 2018).

Flakierska-Praquin, Lindstrom, and Gillberg stated that school refusal behavior has an impact, among others, decreased academic performance. Subjects have difficulty in learning because they rarely attend school. It also affects the academic value of the subject. Teachers also have difficulty evaluating because the student rarely attends school (Ballerina, 2018). Children who experience school refusal have an impact on their learning activities and lead to academic decline. It is as explained by Kearney saying that reluctance and school refusal can occur for various reasons, such as avoiding something that makes him uncomfortable at school or the child showing several physical causes such as headaches or stomach pain when going to school. Children who do school refusal usually experience setbacks in the academic field (Oktaviani \& Nursalim, 2018).

Furthermore, another opinion, Hilmansyah in Suhartanti (2010), states that school phobia has an impact on: (a) Influencing and inhibiting mental growth; (b) Interfering with the process of playing and learning; (c) Declining in academic scores, lack of association; and (d) Disputing in the family.

In other studies, the fear of going to school was identified as a kind of hallucination. Freud, with his psychoanalysis, has become an approach in the interpretation of behavior. Freud is the most discussed figure for unconscious or unconscious existence.

According to Freud, the subconscious mind is full of deep thoughts and emotions and can sometimes express it in various forms, including hallucinations. Freud said that although the subconscious mind is a missing part of sight and its existence is often unconscious, it is a deep conflict that will affect individual behavior. The behavioristic theory argues that school refusal is a reaction to certain learning stimuli related to the school environment. If the stimulus gets reinforcement related to school refusal, then the behavior will be stronger/survive (Nursalim, Hidayah, Atmoko, \& Radjah, 2018).

So in terms of handling, if it is based on Freud's psychoanalysis theory, it can be handled by giving some affirmation or suggestion to change the hallucinations of fear. Meanwhile, it can be handled in terms of behavioristic theory by providing stimuli such as motivation, gifts, or other forms of appreciation. The school refusal actions experienced by children are reduced.

Irrational thought patterns influence the handling of school refusal, in technical counseling guidance that can be provided to refusal school students, namely by providing counseling that is oriented towards changes in cognition, which is centred on the mind, 
which reduces excessive anxiety and fear (Oktaviani \& Nursalim, 2018). It is by changing negative or disturbing thoughts in students into positive thoughts through direction and guidance. Treatments for children who have school refusal should aim to get them back to school as early as possible. Effective trials should be carried out immediately to prevent future problems so that school phobia must be addressed as early as possible.

In the form of school refusals characterized by being reluctant to attend school, intervention models can be handled. This model can be implemented in several steps or ways, as stated by Ballerina (2018): (a) Improve daily monitoring of student attendance; (b) Provide feedback to parents regarding their child's absence; (c) Give awards to students for their attendance; (d) Mediate and seek solutions to children's problems with their parents; (e) Increase children's participation in extracurricular activities or other supportive social activities; (f) Periodically modify the form of giving homework.

Behavioristic interventions for deep school-refusal children can use Contingent Reinforcement for school attendance. The intervention's purpose is to increase deficit behavior, namely being present at school on effective school days. The definition of behavioral contingency refers to a behavior that must be done to get a consequence or behavior that must be done so that certain consequences follow. Positive reinforcement contingency refers to a behavior that must be done to get a positive reinforcer (Ballerina, 2018).

In another case study, it was found that the results of Child-Centered Play Therapy (CCPT) were proven to overcome refusal behavior in a fun and safe way for children. A child no longer cries when he/she wants to sleep at night and when he/she wakes up in the morning, the child no longer says that he/she does not want to go to school, clingy/clingy, anxious, crying, and somatic. The changes experienced by the students are in line with the main objectives of child-centered play therapy, namely self-healing, and well-being (Sri Sunaringsih \& Wati, 2019).

Several research results reveal the treatment of actions for those who reject school in general. These recommendations are (a) testing the school refusal level of the student concerned, (b) conducting a descriptive test to collaborate with the first test scale, (c) carrying out an observation test of student attitudes related to getting the next hypothesis, (d) getting various information from institutions schools to collaborate on hypotheses (Kearney, Chapman, \& Cook, 2005).

\section{CONCLUSION}

This study concludes that; the first was the students' refusal of Madrasah Ibtidaiyah Negeri 1 Semarang occurred for several physical reasons. Most of the reasons they experience was an illness such as dizziness, abdominal pain, and diarrhea. Meanwhile, the psychological reasons were fear because not doing the homework and getting bad treatment/bullying at school results in students getting sick and ultimately refusing to go to school. Second, the students' absence during the learning process, especially in Mathematics, affects their academic achievement. 


\section{REFERENCES}

Andiri, L., Jajat, \& Sulthoni, K. (2017). Hubungan Kecerdasan Emosi dengan Prestasi Akademik Mahasiswa Olahraga. Jurnal Terapan Ilmu Keolahragaan, 2(2). https://ejournal.upi.edu/index.php/JTIKOR/article/view/8063.

Arindiono, R. Y., \& Ramadhani, N. (2013). Perancangan Media Pembelajaran Interaktif Matematika untuk SD Kelas 5. Jurnal Sains Dan Seni Pomits, 2(1). http://ejurnal.its.ac.id/index.php/sains_seni/article/view/2856.

Arofah, I. Z., Hudaniah, \& Zulfiana, U. (2018). Pengaruh Perilaku Bullying terhadap Empati ditinjau dari Tipe Sekolah. Jurnal Ilmiah Psikologi Terapan, 6(1). http://ejournal.umm.ac.id/index.php/jipt/article/view/5435.

Ballerina, T. (2018). Studi Kasus : Penanganan School-Refusal Pada Siswa Sekolah Dasar Berbasis Keluarga. Sosiohumaniora, https://doi.org/10.30738/sosio.v4i1.1625.

Hidayatullah, M. F. (2010). Guru Sejati: Membangun Insan Berkarakter Kuat dan Cerdas. Surakarta: Yuma Pustaka.

Intisari. (2017). Persepsi Siswa Terhadap Mata Pelajaran Matematika. Jurnal Pendidikan Pascasarjana Magister PAI.

Kearney, C. A., Chapman, G., \& Cook, L. C. (2005). Moving from Assessment to Treatment of School Refusal Behavior in Youth. International Journal of Behavioral Consultation and Therapy, 1(1). http://dx.doi.org/10.1037/h0100733.

Kesuma, D. (2013). Pendidikan Karakter: Kajian Teori dan Praktik di Sekolah. Bandung: PT Remaja Rosdakarya.

Manurung, N. (2012). School Refusal Pada Anak Sekolah Dasar. Jurnal Psikologi Undip, 11(1). https://ejournal.undip.ac.id/index.php/psikologi/article/view/5151.

Mintasih, D. (2016). Merancang Pembelajaran Menyenangkan Bagi Generasi Digital. Jurnal Pendidikan Islam, IX(01). http://journal.uii.ac.id/Tarbawi/issue/download/1037/129.

Muslich, M. (2015). Pendidikan Karakter: Menjawab Tantangan Krisis Multidimensional. Jakarta: Bumi Aksara.

Nursalim, M., Hidayah, N., Atmoko, A., \& Radjah, C. L. (2018). Pattern Of School Refusal Behavior On Students; Background, Triggers, Family Profile And Treatment. European Journal Of Education Studies, $4(9)$. https://oapub.org/edu/index.php/ejes/article/view/1782.

Oktaviani, T. L., \& Nursalim, M. (2018). Penerapan Konseling Kelompok Rasional Emotif Perilaku (Rep) Untuk Mengurangi School Refusal (school refusal) Siswa Kelas VIII SMPN 1 Cerme. Jurnal Bk Unesa, 8(1).

Papanastasiou, G. P., Drigas, A. S., \& Skianis, C. (2017). Serious Games in Preschool and Primary School Education: Benefits and Impacts on Curriculum Course Syllabus. IJET, 12(1).

Sri Sunaringsih, M., \& Wati, L. (2019). Studi Kasus: Terapi Bermain Memfasilitasi Perubahan Perilaku Menolak Sekolah. Jurnal Muara Ilmu Sosial, Humaniora Dan Seni, 3(1). https://journal.untar.ac.id/index.php/jmishumsen/article/view/3765. 
Sucipto. (2012). Bullying dan Cara Meminimalisasikannya. Psikopedagogia, 1(1). http://journal.uad.ac.id/index.php/PSIKOPEDAGOGIA/article/view/2566.

Sugiyono. (2005). Memahami Penelitian Kualitatif dilengkapi Contoh Proposal Penelitian. Bandung: Alfabeta.

Suhartanti, I. (2010). Peran orang tua Menghadapi School Phobia pada Anak Usia Pra Sekolah (4-6 Tahun) di Tk Nurul Huda Jabon Mojokerto. Hospital Majapahit, 2(2). http://ejournal.stikesmajapahit.ac.id/index.php/HM/article/view/32.

Sukmadinata, N. S. (2012). Metode Penelitian Pendidikan (Cet. 8). Bandung: PT Remaja Rosdakarya. 